\title{
MANAGEMENT OF FINANCIAL RESOURCES FOR SCIENTIFIC RESEARCH AT UNIVERSITIES IN ROMANIA
}

\author{
Margareta Stela Florescu, Sorin Burlacu, Cristina Manole \\ Faculty of Public Administration and Management, Academy of Economic Studies, \\ Bucharest, Street Caderea Bastiliei no. 2-10, 010374, Romania, \\ margareta.florescu@ari.ase.ro
}

\begin{abstract}
The issue of funding scientific research becomes particularly important given that research is one of the main areas that help to reduce disparities between the economies internationally. Thus, the competitiveness of a country is a general objective that can be achieved by pursuing two fundamental objectives: the generation and exploitation of knowledge.
\end{abstract}

Keywords: Management, finance, strategy, scientific research,

\section{Introduction}

In the context of globalization, the creation of international scientific community strengthened through cooperation and exchange of knowledge between countries. In this context it is important the need for measures concerning the generation and exploitation of knowledge to be translated differently to national depending on countryspecific factors of influence. In this arena, one of the significant players have become universities, higher education is considered a sector performance, which is designed to act on this market knowledge aimed at this attraction and development of human resources and attract funding sources. From this perspective, it is necessary for universities to focus their objectives and resources on research, development and innovation as drivers of a competitive economy.

Based on the points raised, about the importance and role of research, this paper seeks to examine whether the research in Romania is seen as a strategic objective, by reference to the level of funding in this area.

The impact of research funding from public funds on society and the economy has become a central concern of bodies policymakers in these areas, as changes in the role of governments and public research institutions have led to an increased demand for policies based on proven practices and to assess the results of public investment. (OECD, 2008)

\section{ANALYSIS ON RESEARCH FUNDING IN ROMANIA academics}

\subsection{Context analysis}

The proposed research problem focuses on the importance of funding and access to funding sources for scientific research at universities in Romania.

\subsection{Research methodology}

In this research were used the following methods and tools:

- Methods of data collection: questionnaire structured databases institutional analysis, document analysis;

- Tools to support the systematization, analysis and interpretation of results: Microsoft Office Excel 2010, IMB SPSS Statistics V20, Ishikawa diagrams,

\subsection{Method of analysis: Questionnaire}

The main tool used for data collection was questionnaire, presented in "Annex 1 questionnaire was administered via Google 
Drive platform. Proposed sample composed of 19 universities Government of Romania; responses were recorded in databases, avoiding manual records.

Operating in Romania in 2012, according to data published by the National Institute of Statistics ${ }^{1} 57$ public universities (state) and 51 private universities accredited or authorized to function temporarily, comprising 28365 teachers, representing approximately $55 \%$ of all employees in the system. Observation unit of the survey was represented by public universities in Romania, research sample consisting of 179 teachers $^{2}$ of 19 public universities in Romania, accounting for 33.33\% of all public universities in Romania. Why build sample is limited only to public universities is that, according to the classification of universities by the Ministry of Education, no private university in Romania does not fall among institutions dedicated to research, all of which are listed in the lower level in terms of quality (universities focused on education). Thus, they were comparable in terms of research activity.

Beneficiaries research results are represented primarily by the participants in this research, because by expressing their views have contributed and influenced the results of this research. However, as this research has focused national research system, the results of this research can primarily benefit all institutions of academia, academic and even other important players in the field of research institutes and research centers, as well as actors of the private sector.

\subsection{Analysis items for consistency evaluation questionnaire - Alfa Coefficient Cronbach's}

The alpha coefficient, referred to as the Cronbach alpha $(\alpha)$ was proposed by American psychometrician Lee J. Cronbach in 1951 as a generalization coefficient KuderRichardson (KR) for dichotomous response items. Importance of Cronbach alpha

1 Qregards the higher education. The beginning of the 2011-2012 academic year. statistical notebookNational Institute of Statistics, 2012. coefficient size can be better understood if we place on the field relationship between validity and reliability (Cronbach, 1963, p. 137).

Cronbach alpha expression for calculation is as follows:

$$
\alpha=\frac{N * r_{m}}{1+(N-1) * r_{m}}
$$

\section{Figure 1. Cronbach Alpha expression calculation}

where: $N=$ Number of items, $r m=$ The average of the correlation coefficients of the items. After the initial application on 35 questionnaire respondents, the analysis was performed questionnaire items that made by Alfa Cronbach's coefficient calculation. The initial value of this coefficient, calculated by means of the SPSS software was $\alpha=0,576$. Deşi in literature was not identified an absolute standard with eyes the size that should be Cronbach's alpha coefficient to indicate a corresponding fidelity generally about 0.90 values are considered "excellent", around 0.80, "very good", while around 0.70 , "good" (Kline, 2005). There are also authors who accept a value of 0.60 , but only exploratory studies (Garson, 2010).

Given the fact that the coefficient of importance in checking research tool as it checks practical consistency and safety items that make up the questionnaire, to correlate the items, we considered the need to adjust this indicator was achieved by eliminating items which set negative, leading to a final value $\alpha=0.690$, representing an acceptable coefficient.

programs IMB SPSS Statistics and Microsoft Excel were used:

- editing data (building the database by introducing the results of the questionnaire, coding variables);

- statistical processing of data (descriptive statistics, testing the fidelity items by calculating Cronbach alpha indicator);

${ }^{2}$ Getting information was taken from the database UEFISCDI Source: http:

//www.cercetatoriromani.ro/search_operator.php 
- presentation and interpretation of the results in tabular form or graphics.

Regarding the main characteristics of the sample, the following can be stated, starting from the following graphic and tabular representations: Of the 19 public universities that participated in the research respondents are primarily universities of advanced research and education (61\%), followed by university education and scientific research (31\%) and only $8 \%$ of respondents from universities mainly education.

Table. 1: Distribution of respondents by category falling university of origin

\begin{tabular}{|l|c|c|c|c|}
\hline & $\begin{array}{c}\text { Frequ } \\
\text { ency }\end{array}$ & Percent & $\begin{array}{c}\text { valid } \\
\text { Percent }\end{array}$ & $\begin{array}{c}\text { cumulat } \\
\text { ive } \\
\text { Percent }\end{array}$ \\
\hline $\begin{array}{l}\text { Mostly } \\
\text { university } \\
\text { education }\end{array}$ & 15 & 8.4 & 8.4 & 8.4 \\
\hline $\begin{array}{l}\text { University } \\
\text { education } \\
\text { and valid } \\
\text { scientific } \\
\text { research }\end{array}$ & 55 & 30.7 & 30.7 & 39.1 \\
\hline $\begin{array}{l}\text { University } \\
\text { Advanced } \\
\text { Research } \\
\text { and } \\
\text { Education }\end{array}$ & 109 & 60.9 & 60.9 & 100.0 \\
\hline Total & 179 & 100.0 & 100.0 & \\
\hline
\end{tabular}

Regarding distribution by grade of those 179 respondents, according to the chart below one can see that $31 \%$ of them are CS3 / Lecturer, 30\% are CS1 / Teacher, 29\% CS2 / Lecturer, 7\% CS / Assistant and 3\% were PhD students.

\subsection{Analysis of research results}

The first question, concerning the establishment of specialized structures research revealed the following aspects: only $4 \%$ of universities that participated in the research were not established any kind of specialized body of research, while $43 \%$ of universities structures were established specialized research faculties in 33\% across departments and $20 \%$ at the department level.

Thus, it can be seen concern universities in Romania to create specialized research structures. Determination of this issue, however, is not the whole story, because it shows only a trend, so that it becomes more important for research to see if this affects any extent to obtain funding for scientific research.

The rate of access to various sources of research funding is very high, as only $1 \%$ of respondents said they had not accessed any source of funding for scientific research. Regarding access to funding sources, it can be seen that $44 \%$ received national public funding, 34\% benefited from European funding, $18 \%$ received funding from contracts with the private sector and $3 \%$ from other sources. The category "Other sources of funding" were mentioned by respondents: international funding, civil agreements, service contracts, consulting agreements, internal grants of the Department for stimulating young people.

To check the correlation between the two nominal variables it was calculated in SPSS Phi coefficient - a coefficient is calculated for two dichotomous variables and nominal record, in particular, the presence or absence of a feature.

Phi coefficient values for the variables analyzed are as follows:

\section{Table no. 2: The values of the coefficient Phi}

Symmetric Measures: No funding source units * The existence of research and development at universities

\begin{tabular}{|l|l|r|r|}
\hline & \multicolumn{2}{|c|}{ Value } & \multicolumn{2}{c|}{ Approx. Sig. } \\
\hline $\begin{array}{l}\text { Nominal by } \\
\text { Nominal }\end{array}$ & & .840 & .01 \\
\hline $\begin{array}{l}\text { Valid N } \\
\text { of Cases }\end{array}$ & 179 & & 0 \\
\hline
\end{tabular}

Symmetric Measures: * The existence of national public funding of $R \& D$ units in universities

\begin{tabular}{|c|c|c|c|}
\hline & Value & \multicolumn{2}{|c|}{ Approx. Sig. } \\
\hline $\begin{array}{l}\text { Nominal by } \\
\text { Nominal }\end{array}$ & \begin{tabular}{l|l} 
Phi & \\
\end{tabular} & .413 & $\begin{array}{r}02 \\
0\end{array}$ \\
\hline $\begin{array}{l}\text { Valid N } \\
\text { of Cases }\end{array}$ & 179 & & \\
\hline
\end{tabular}


Symmetric Measures: European

Financing * The existence of R \& D units in universities

\begin{tabular}{|l|r|r|r|}
\hline & \multicolumn{2}{|c|}{ Value } & \multicolumn{2}{c|}{ Approx. Sig. } \\
\hline $\begin{array}{l}\text { Nominal } \\
\text { by Phi }\end{array}$ & .209 & .0 \\
Nominal & & & 50 \\
\hline $\begin{array}{l}\text { Valid N } \\
\text { of Cases }\end{array}$ & 179 & \\
\hline
\end{tabular}

Symmetric Measures: * Existing contracts with the private sector $R \& D$ units in universities

\begin{tabular}{|l|c|c|r|}
\hline & \multicolumn{2}{|c|}{} & \multicolumn{2}{c|}{ Approx. Sig. } \\
\hline $\begin{array}{l}\text { Nominal } \\
\text { by Phi }\end{array}$ & .159 & .0 \\
Nominal & & & 50 \\
\hline $\begin{array}{l}\text { Valid N } \\
\text { of Cases }\end{array}$ & \multicolumn{1}{|c|}{179} & \\
\hline
\end{tabular}

Symmetric Measures: Other funding sources * Existing R \& D units in universities

\begin{tabular}{|l|l|r|r|}
\hline & \multicolumn{2}{|c|}{ Value } & \multicolumn{2}{c|}{ Approx. Sig. } \\
\hline $\begin{array}{l}\text { Nominal } \\
\text { by }\end{array}$ & & .177 & 13 \\
Nominal & & & 2 \\
\hline $\begin{array}{l}\text { Valid N } \\
\text { of Cases }\end{array}$ & \multicolumn{2}{|c|}{179} & \\
\hline
\end{tabular}

According to the data in the table above, the following interpretations can be made based on the coefficient values Phi: phi coefficient value is greater than 0.8 in the first joint, which causes a strong association between the first two variables that can be generalized as follows: lack of research units associated with no accessing research funding. On the other hand, the intensity of the association for the next two correlations is much lower, but it can be considered valid, it can argue that the existence of research units in universities facilitate access to funding through national and European programs. On the other hand, the last two associations under phi coefficient, are invalid.

The correlation of responses to the two questions on the two variables (the structures and attracted financing sources). The results can be seen in the following chart:

Chart 1: Correlation between types of funding attracted and the structures specialized research in Universities

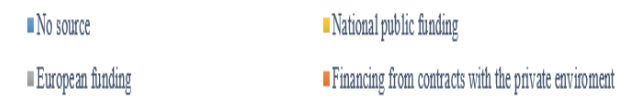

IOther sources of finding
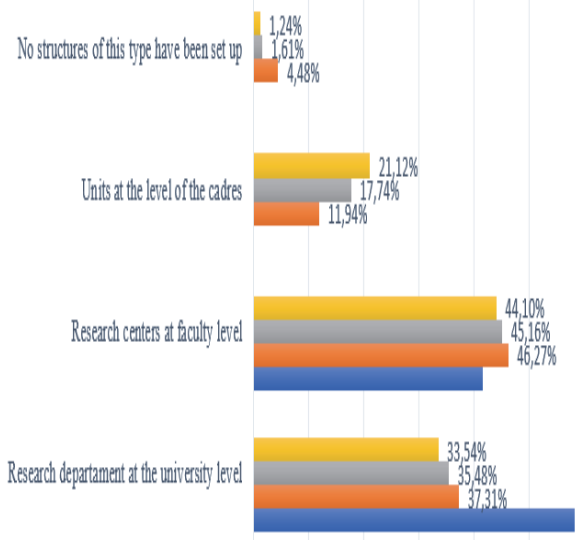

0,00\% 1000\% 20,00\% 30,00\% 40,00\% 50,00\% 60,00\% 70,00\%

Figure 2. Correlation between types of funding attracted and the structures specialized research in Universities

From the chart above, it appears that there is a significant association between access to different types of financing and existing structures at universities specialized research. The main arguments in this respect are: respondents who said they were not established specialized structures are the ones who have not won any source of research funding, while for universities that have established specialized units (the departments, faculties or universities) can see that they have access, to varying degrees, all research funding.

In this respect, the chart below shows the factors influencing the research measured the intensity allocated to each factor by respondents. 
Chart. 2: To what extent do the following issues have influenced / may affect research projects?

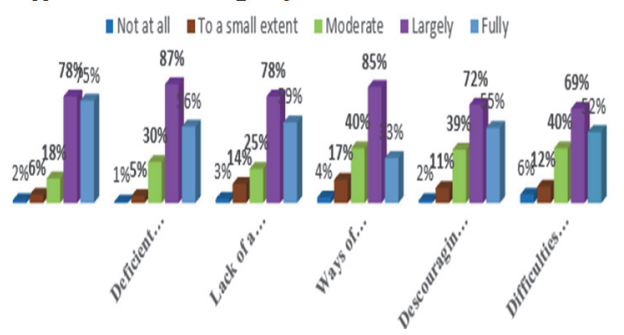

Under-funding the national CD system

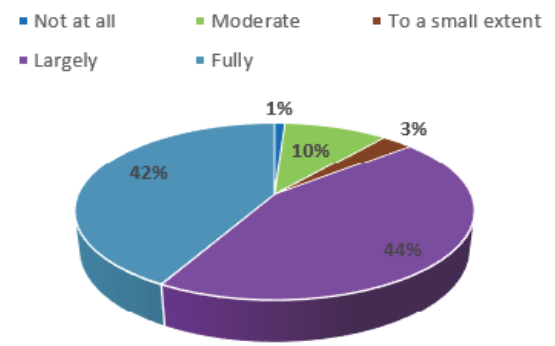

Deficient management of public funding mechanisms by authorities
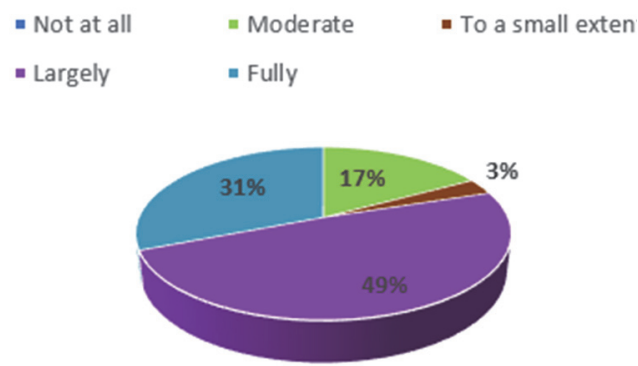

Lack of a CD strategy

$\begin{array}{ll}\text { - Not at all } & \text { - Moderate } \\ \text { - Largely } & \text { - Fully }\end{array}$

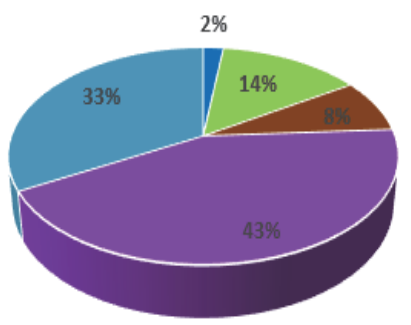

Ways of funding do not reward quality and performance

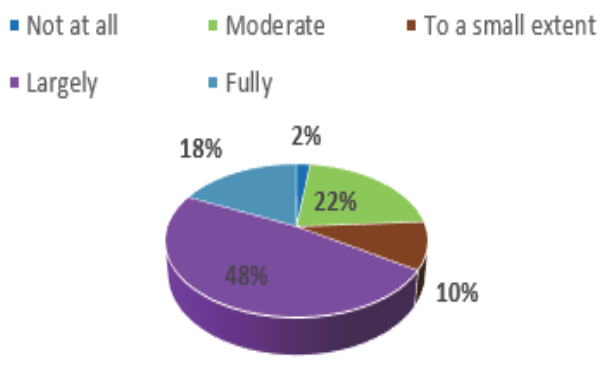

Lack of transparency in the funding process

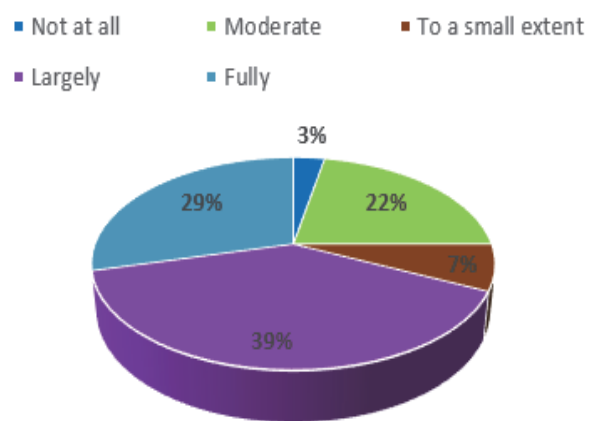

Discouranging formalities

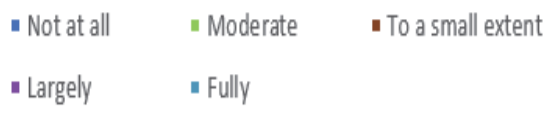

$1 \%$

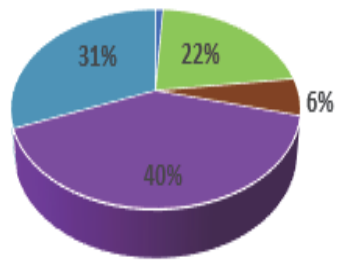

Figure 3. To what extent do the following issues have influenced / may affect research projects?

Among the factors that most influence the research includes: poor management of public funding mechanisms by the authorities and funding arrangements which focus on performance and quality. Also, other significant factors were: The National 
Research underfunding and lack of strategies in domain. However, according to the schedule above could be achieved only separate analysis for each of the items, making it difficult to compare factors. The table below highlight trends on the factors influencing research, the average was calculated for each factor, the results can then be compared.

Table no. 3: To what extent do the following issues have influenced / may affect research projects?

\begin{tabular}{||l|c|c|c|c|c||}
\hline \multicolumn{1}{|c|}{ item } & N & $\begin{array}{c}\text { Mi } \\
\text { n. }\end{array}$ & $\begin{array}{c}\text { M } \\
\mathbf{a x}\end{array}$ & Mean & $\begin{array}{c}\text { Std. } \\
\text { devi } \\
\text { ation }\end{array}$ \\
\hline $\begin{array}{l}\text { Lack of } \\
\text { finances } \\
\text { national }\end{array}$ & 179 & 1 & 5 & 4.22 & .843 \\
\hline $\begin{array}{l}\text { Poor } \\
\text { managemen } \\
\text { t of public } \\
\text { funding } \\
\text { mechanisms }\end{array}$ & 179 & 1 & 5 & 4.07 & .800 \\
\hline $\begin{array}{l}\text { The lack of } \\
\text { a coherent } \\
\text { in the art }\end{array}$ & 179 & 1 & 5 & 3.98 & .968 \\
\hline $\begin{array}{l}\text { Funding } \\
\text { criteria }\end{array}$ & 179 & 1 & 5 & 3.70 & .952 \\
\hline $\begin{array}{l}\text { Formalities } \\
\text { access }\end{array}$ & 179 & 1 & 5 & 3.93 & .934 \\
\hline $\begin{array}{l}\text { Reimburse } \\
\text { ment issues }\end{array}$ & 179 & 1 & 5 & 3.83 & 1030 \\
\hline $\begin{array}{l}\text { The degree } \\
\text { of } \\
\text { transparenc } \\
\text { y in } \\
\text { financing }\end{array}$ & 179 & 1 & 5 & 3.65 & 1062 \\
\hline \hline $\begin{array}{l}\text { Valid N } \\
\text { (listwise) }\end{array}$ & 179 & & & & \\
\hline \hline
\end{tabular}

It can be seen from the table above, the factor which, according to media responses and was given utmost importance is the national system underfunding, followed by poor management of public funding mechanisms. The environments are relatively close, with no values below 3.65, which means that each of the six factors of importance raised in relation to access to funding sources for research in academia Romanian. Based on data collected on these issues, it was possible an Ishikawa diagram, serving to highlight the causes and effects previously determined factors as causes of poor funding of scientific research in Romania.

Figure 4: Ishikawa diagrams - factors influencing research in Romania

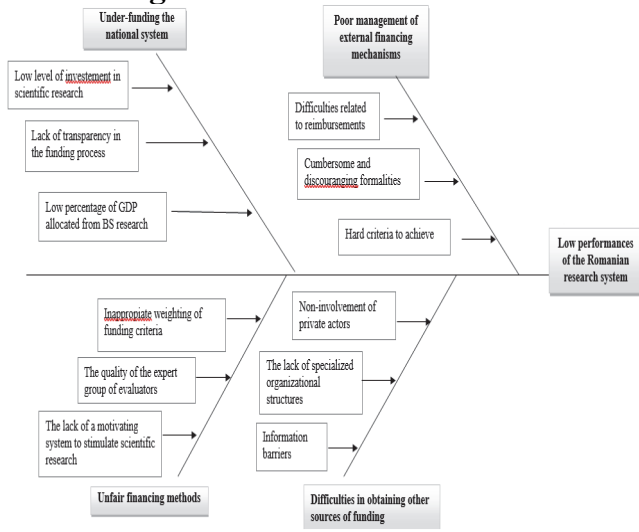

Ishikawa diagram as a tool for analysis, offered a systematic way of looking at the effects and causes which contribute or may contribute to unsatisfactory results of Romanian research and is a diagram of cause - effect. Through the above diagram could be identified several reasons why the research system in Romania doesn't function appropriate, the main ones being:

- underfunding of the National Research

- poor national management of external financing instruments

- arrangements (criteria) funding unfair

- difficulties in obtaining other sources (private) research funding

The research has observed the following trends:

- increasing the number of articles, studies published abroad is the $1^{\text {st }}$ priority $(24.02 \%$ appreciated the sources of funding obtained were used wholly for this activity and $40.78 \%$ felt that they were used to a large extent this direction);

- $\mathrm{R}$ infrastructure development is the $2^{\text {nd }}$ priority $(16.20 \%$ appreciated that such sources of funding that have been fully used obtained for this activity, and $42.46 \%$ appreciated that to a large extent);

- the $3^{\text {rd }}$ direction they were facing funding sources, is the development of human resources for research, $32.96 \%$ consider that it has been considered fully and $10.06 \%$ in a widely; 
- the last two activities, appreciated by respondents as those who were targeted funding to a lesser extent were organizing national and international scientific and management modernization to increase institutional capacity for development research.

- in mostly (29\% of respondents) research results were used in universities and secondly, a significant percentage (22\%) of respondents have stated that research results have not been applied in any field. This is explained by the fact that not all research had practical tool, but rather many were just basic research. Also, by a large number of responses it was revealed that much of the research have been applied in the national research institutes.

- An interesting aspect of the survey was to see that much of the research results were taken from the private sector $(15 \%$ accounted for $2 \%$ of SMEs and multinationals).

- It was pointed out that if sources of funding through contracts with the private sector, research results are used in a significant percentage still in academia (30.99\%), and research institutes $(30.99 \%)$, and in the private sector $(31.69 \%)$. A similar trend observed for a national funding, hence the fact that over $70 \%$ of the research results are implemented in universities and national research institutes, while a significant share of approximately $22 \%$ is allocated to the private sector.

\section{Conclusions}

Scientific research is an important driver of economic competitiveness of a country. For the management and financing activities in this field at national level will depend on significant results of scientific research and the degree of innovation, quality and how will it be used will significantly affect international hierarchy of the most powerful and competitive economy, a knowledge-based society.

In the analysis research results at universities in Romania, it allowed the determination of multiple factors that hinder scientific accessing funding sources, especially at national level. The most significant of these are: The National Research underfunding, poor management of public funding mechanisms by the authorities, financing not focus on performance and quality, lack of vision and a coherent strategy in the field.

Another important aspect determined from the research is that scientific research in universities in Romania has a profound theoretical majority being of fundamental research. Lack of applied research is an issue that requires a focus for promoting such research may lead to engaging the private sector in financing research, private actors can be beneficiaries of the activities. Currently, in Romania, according to the study, it was observed that research findings apply particularly in academia, followed by institutes and centers of research and development and the private sector.

There are limits to the research, namely: - Lack of complete database and adapted to include all researchers from Romanian university made it impossible sampling using statistical methods, such as one random sampling, which led to a differentiated representation of respondents in universities;

- The main data collection tool (questionnaire), failed to observe all possible variables coverage and research, some of them leading to incomplete analysis, but may however be subject to further research;

- The analysis is limited to a study of academic research, no comparisons were made with other important actors in Romania: academia, national research institutes. Such an analysis might reveal an overview of research activity in Romania.

\section{Bibliography}

1. AGACHI S., COCEAN R., (2011), research management, Executive Unit for Financing Higher Education, Research, Development and Innovation

2. CASSIMAN, B., GAMBARDELLA, A., (2009), "Strategic organization of R \& D" in Nickerson, J., B. SILVERMAN, Economic Institutions of Strategy (Advances in Strategic Management, Vol. 26), Emerald Group Publishing Limited, pp.39-64

3. Choi YJ, Lee, HJ, SOHN, YJ, (2009), "Impact Analysis R \& D Funding for the National Science and Technology in quanti as cation Using Method II" Policy Research 38, 
Elsevier

4. DOUGHERTY, MS, Robert INKLAAR,

R. (2007) "International Comparisons of R \&

D Expenditure. Year R \& D PPP Does Make a

Difference? ", National Bureau of Economic

Research, University of Chicago Press

5. Florescu, M., S., (2006) Management of scientific research ASE, Bucharest

6. Florescu, M., S., (2010), Analysis of European funds by Romania's participation in FP7 projects, Transylvanian Review of Administrative Sciences 2 (26) / 2010

7. GARSON, D., (2010), "Statnotes: Topics in Multivariate Analysis - Reliability Analysis 8. MIROIU, A., MURGESCU, B., (2013), State higher education funding - Annual Public Report - 2012 Report adopted by the National Council for Higher Education at the meeting on April 3, 2013

9. Santamaria L, BARGE-Gil A., MODREGO, A., (2010), "Public selection and financing of $\mathrm{R} \& \mathrm{D}$ cooperative projects:
Funding subsidy versus Credit" Policy

Research 39, Elsevier

10. WILSON, Bright, E. (1990), "An introduction to scientific research", General Publishing Company, Ontario

11. European Commission - Eurostat (2013), "Statistical Requirements Compendium" Methodologies and Working papers, Theme 5.06: Science, technology and innovation 12. http:

//www.insse.ro/cms/rw/pages/index.ro.do 13. http:

//epp.eurostat.ec.europa.eu/portal/page/portal /eurostat/home/

14. http:

//data.worldbank.org/indicator/GB.XPD.RS

DV.GD.ZS

15. http:

//ec.europa.eu/eurostat/ramon/nomenclatures /index.cfm?TargetUrl=LST_NOM_DTL_GL OSSARY\&StrNom=CODED2\&StrLanguag eCode $=\mathrm{EN}$ 